\title{
The effect of and interaction between the biological bases and the agrotechnical factors on maize yield
}

\author{
Péter Kovács \\ University of Debrecen Faculty of Agriculture, Food Sciences and Environmental Management, \\ Institute of Plant Sciences, Debrecen \\ kovacs.peter@agr.unideb.hu
}

SUMMARY

In our research, we examined the effect of the hybrid, the nutrient supply, the number of plants and the abiotic factors (temperature, amount of precipitation) on the yield, crop quality and yield stability of maize. We devoted special attention to the natural nutrient utilization ability and fertilizer reaction of maize. The experiment took place in Hajdúszoboszló on chernozem soil, on a nearly 8 ha field. The size of one plot was $206 \mathrm{~m}^{2}$; therefore, this experiment was half-industrial. We tested six hybrids with different genetic characteristics and growing seasons. We analysed the correlation between the nutrient supply and the yield of maize hybrids with a control treatment (treatment without fertilization) and with $\mathrm{N} 80, \mathrm{P}_{2} \mathrm{O}_{5} 60, \mathrm{~K}_{2} \mathrm{O} 70 \mathrm{~kg} \mathrm{ha}{ }^{-1}$ and $\mathrm{N} 160, \mathrm{P}_{2} \mathrm{O}_{5} 120, \mathrm{~K}_{2} \mathrm{O} 140 \mathrm{~kg} \mathrm{ha}$ fertilizer treatments. The yield increasing effect of the fertilizer also depended on the number of plants per hectare to a great extent. The number of plants of the six tested hybrids was 60 , 70 , and 80 thousand plants $h a^{-1}$.

In 2015, the highest yield was produced by hybrid P9241 with $N_{80}+P K$ and 70 thousand plants per hectare. With the $N_{160}+P K$ fertilizer dosage, the same hybrid responded the best, followed by hybrids $P 9486$ and DKC4717. Using the same fertilizer treatment, the 80 thousand plants per hectare population density resulted in decrease in the yield with most of the examined hybrids. In 2016, with the increase in the number of plants per hectare, even with non-fertilised treatment (control treatment), the yield could be increased in the case of each hybrid. Averaged over the different hybrids and fertilizer treatments, applying 80 thousand plants ha ${ }^{-1}$ instead of 60 thousand resulted in 1.0 ha ${ }^{-1}$ yield increase. In 2017, the number of plants had a slighter effect. With $N_{160}+P K$ treatment, in most cases no significant difference can be observed. The value of $L S D_{5 \%}$ : plant number: $0.20 \mathrm{t} h \mathrm{a}^{-1}$, hybrid: $0.28 \mathrm{t} \mathrm{a}^{-1}$, interaction: $0.48 \mathrm{t}$ ha $\mathrm{a}^{-1}$ With $\mathrm{N}_{160}+\mathrm{PK}$ treatment, the hybrids produced yields between 10.07 and $12.45 \mathrm{tha}^{-1}$. When examining the three years in the average of the number of plants, with treatment without fertilisation, the average yield of hybrids reached $7.53 \mathrm{t} \mathrm{ha}^{-1}$. With $\mathrm{N}_{80}+\mathrm{PK}$ treatment, this value was $9.71 \mathrm{t}$ ha ${ }^{-1}$ and with doubling the fertilizer dosage, this value increased to $10.42 \mathrm{th} \mathrm{a}^{-1}$. No economic profit was gained as a result of applying double dosage of fertilizer; therefore, the $N_{80}+P K$ dosage can be considered ideal.

Keywords: maize, nutrient supply, number of plants, crop year effect, hybrid

\section{INTRODUCTION}

The crop year has a strong effect on the efficiency of the production of maize, and its unfavourable effects has to be counteracted with agrotechnical elements and with choosing the appropriate genotype, which, in the future, will play an increasing role due to global warming. One of the most important tasks is to choose a favourable type of soil, but in addition to the appropriate soil characteristics, it is also of high importance to choose the suitable hybrid and to work out an agrotechnique which provides conditions that meet the needs of that hybrid. Also, it has to be taken into account that among the climatic factors, maize is highly sensitive to the water supply (Pepó 2006). Namely, the amount of precipitation and its temporal distribution play a decisive role, as for a higher yield a bigger amount of precipitation is essential (Nagy 2006).

The main problem in maize production in Hungary is the fluctuation in the yield, which could be clearly detected in the last three years, the national average yield was $5.7 \mathrm{t} \mathrm{ha}^{-1}$ in 2015, $8.6 \mathrm{t} \mathrm{ha}^{-1}$ in 2016, and 6.66 $\mathrm{t} \mathrm{ha}^{-1}$ in 2017 on 1.014 million ha (NAK 2017). The annual national average yields are extremely affected by the amount of precipitation in the different crop years. In the last 120 years (in the Debrecen area) the average precipitation of many years has decreased by
$121 \mathrm{~mm}$, which trend is continuing. The precipitation is decreasing mainly in the summer months, which has an adverse effect especially on stoop crops, thus on maize as well. Drought damage can be reduced primarily by biological and agrotechnical factors, appropriate crop rotation, harmonized NPK nutrient supply, by choosing hybrids with good adaptability, suitable for the given ecological characteristics and with reduction in the number of plants per unit area (Futó and Sárvári 2015). According to Marton's (2014) experiments, under optimum conditions, the yield of new hybrids is not higher than or just hardly exceeds that of the older hybrids. Compared to the older hybrids, their advantageous characteristics are proved mainly in conditions of stress. The effect of the crop year affects the efficiency of fertilizer treatments as well, since treatments with larger amount of NPK fertilizers have stable influence in drought crop years, while in those with more precipitation, their efficiency is stronger (Berzsenyi and Györffy 1997). That fact has been confirmed by Lente and Pepó (2009) who also found that the yield of maize was influenced mainly by the water supply in the given crop year, and it determined the optimum number of plants, too. On the other hand, a longer droughty and steady warm period can also narrow the natural capability of nutrient uptake of plants (Nagy 1995). The water supply significantly determines the efficiency of 
fertilization as well, because larger dosages of fertilizers can reduce the yield with insufficient amount of water (Rácz and Nagy 2011). According to the results of Nagy's (2017) long-term experiment conducted through 25 years (1990-2016), there is a significant difference in the average yield of maize between rainy and droughty years. In droughty years the average yield was $6.95 \mathrm{t} \mathrm{ha}^{-1}$, while the favourable water supply resulted in a considerable yield increase (by $2.14 \mathrm{t} \mathrm{ha}^{-1}$ ).

In the production of maize, in addition to the ecological and agrotechnical factors, the biological bases are also of high importance, which contribute to the yield increase in 50\% (Nagy and Huzsvai 2005). According to Györffy (1976), choosing the appropriate hybrid influences the yield increase in $26 \%$, which is $32.6 \%$ according to Berzsenyi et al. (2011) and Bocz (1981) determined it as 25\%. Among agrotechnical factors, the nutrient supply and the plant are the two factors that affect the yield as well as the yield stability. The appropriate nutrient supply determines the yield in $26 \%$ according to Györffy (1976), in 30.6\% according to Berzsenyi et al. (2011), in $48 \%$ according to Nagy (1996), and in $39.3 \%$ according to Pepó and Csajbók (2014). They attached less importance to the appropriate plant number: Berzsenyi et al. (2011) 20.8\%, Nagy (1996) 6\%, Pepó and Csajbók (2014) 8\%. Based on the result of the examinations in years 1981-2001, Pepó et al. (2002) considered that besides genotypes, the crop year also had a strong influence on the response of the hybrids to the number of plants. While the differences caused by the varied plant numbers are infinitesimal in droughty crop years, in an average crop year they are more likely to become determining factors. In a droughty crop year, the highest yield was measured with 50 thousand plants ha ${ }^{-1}$, and with a plant number higher than that the yield was significantly lower. In an average crop year 67-73 thousand plants $\mathrm{ha}^{-1}$, in a favourable crop year 79 thousand plants $\mathrm{ha}^{-1}$ stand density seems to be the optimum. However, in practice, a lower number, 65-73 thousand plants ha ${ }^{-1}$ can be recommended depending on the genotype, the technical background, the level of inputs and the characteristics of the place of production, in the Debrecen area. When evaluating the results of his experiments of many years, Sárvári (2006) concluded that with increasing the number of plants by 10.000 plants $\mathrm{ha}^{-1}$ the yield can increase even by $1.5-2 \mathrm{t} \mathrm{ha}^{-1}$, in favourable circumstances, while in droughty conditions it can decrease by the same extent.

The aim of the experiment was to examine the effect of the hybrid, the nutrient supply, the number of plants and the abiotic factors (temperature, amount of precipitation) on the yield, crop quality and yield stability of maize.

\section{MATERIAL AND METHODS}

Our experiment took place in Hajdúszoboszló on calcareous chernozem soil, on a nearly 8 ha land. The size of one plot was $206 \mathrm{~m}^{2}$, thus it was a half- industrial experiment. We tested six hybrids with different genetic characteristics and growing seasons. The correlation between the nutrient supply and the yield of maize hybrids was analysed with control treatment (treatment without fertilization) and with $\mathrm{N}$ $80, \mathrm{P}_{2} \mathrm{O}_{5} 60, \mathrm{~K}_{2} \mathrm{O} 70 \mathrm{~kg} \mathrm{ha}^{-1}$ and $\mathrm{N} 160, \mathrm{P}_{2} \mathrm{O}_{5} 120, \mathrm{~K}_{2} \mathrm{O}$ $140 \mathrm{~kg} \mathrm{ha}^{-1}$ fertilizer treatments. In our experiment, the same fertilizer dosages have been applied for the $2^{\text {nd }}$ year now (it is not a long-term experiment). The yield increasing effect of the NPK fertilizer depended also on the number of plants per hectare at a great extent. The plant number of the six tested hybrids was $60,70,80$ thousand plants $\mathrm{ha}^{-1}$.

In our research, we analysed the effect of the hybrid, the nutrient supply, the number of plants and the abiotic factors (temperature, precipitation) on the yield, yield quality and yield stability. The natural capability of nutrient uptake and usage and the fertilizer response of maize were expressed in numbers. Values of the gained results were evaluated by using SPSS 22.0 programme, applying multifactor variance analysis.

In Hajdúszoboszló, from January to October in 2015, the amount of precipitation was $340.3 \mathrm{~mm}$, which is $105.5 \mathrm{~mm}$ less than the average of 30 years (Figure 1). In the crucial months of the crop year the distribution of precipitation was unfavourable for maize, it was less by $31 \mathrm{~mm}$ in June and less by 42 $\mathrm{mm}$ in July. Between 9 and 17 July, in a nearly 40 days long period, only $8 \mathrm{~mm}$ of rain fell (1-2 $\mathrm{mm}$ a day), when the number of days of extreme heat was 30 and the number of hot days was 16 . The average monthly temperature was $2.6{ }^{\circ} \mathrm{C}$ higher in July and $3.7^{\circ} \mathrm{C}$ higher in August than the average of many years.

Figure 1: The weather at Hajdúszoboszló in 2015

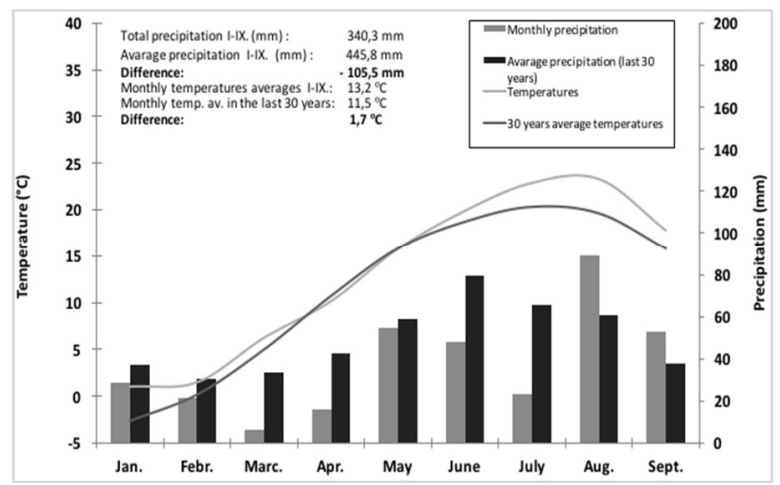

In 2016 the crop year was favourable for stoop crops. The distribution of precipitation was especially advantageous. Due to climate changes, mainly in the summer months, the amount of rain decreased. But in 2016, in contrast with the previous year, June and July were rainy, which increased the yield and yield stability of maize. In Hajdúszoboszló, in 2016, the total amount of rain from January to October was 605 $\mathrm{mm}$ which is by $160 \mathrm{~mm}$ more than the average of 30 years (Figure 2). Except for April, in each month, the amount of precipitation was above the average. It was especially ideal that also in the period of flowering, 
fertilization and grain filling plenty of water was available. It considerably contributed to the outstanding yield results.

Figure 2: The weather at Hajdúszoboszló in 2016

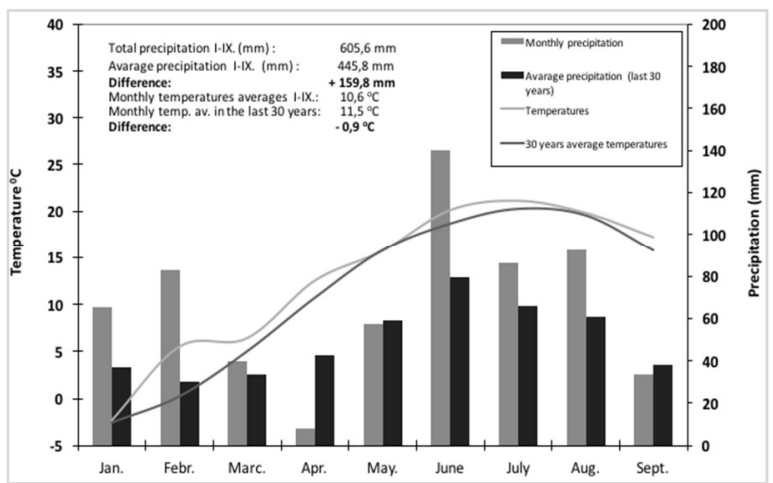

In 2017, up to October, $446 \mathrm{~mm}$ of rain fell, which is in line with the average values of 30 years, and is only $46 \mathrm{~mm}$ less than those (Figure 3). Although in May only $28 \mathrm{~mm}$ of precipitation fell, which is half of the usual amount, in the period most critical for maize (during flowering and fertilization) the amount of precipitation was adequate, and there was no extreme value among the monthly temperature data either. Thus, it can be considered as an absolutely average year.

Figure 3: The weather at Hajdúszoboszló in 2017

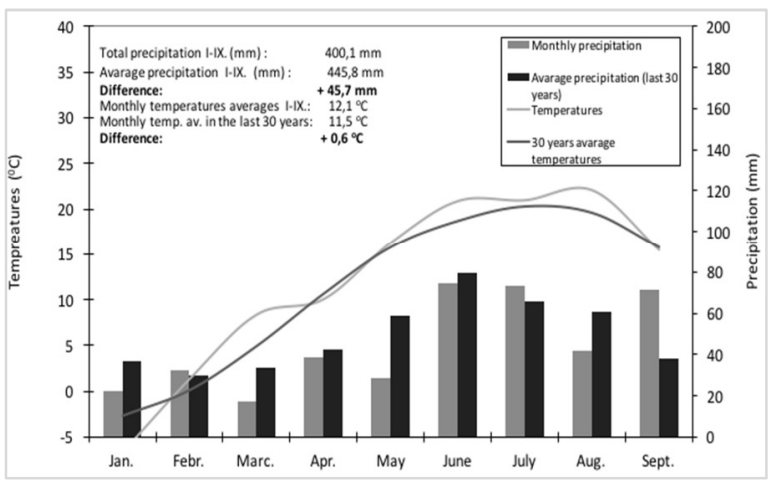

\section{RESULTS AND DISCUSSION}

In 2015, the highest yield, $8.03 \mathrm{t} \mathrm{ha}^{-1}$, was produced by hybrid P9241, with $\mathrm{N}_{80}+\mathrm{PK}$ treatment and 70 thousand plants $\mathrm{ha}^{-1}$. Also with $\mathrm{N}_{160}+\mathrm{PK}$ fertilizer dosage this same hybrid had the best result, and it was followed by hybrids P9486 and DKC4717. With those treatments, the highest number of plants, 80 thousand plants $\mathrm{ha}^{-1}$, reduced the yield of most of the hybrids (Figure 4). The decrease was lower with $\mathrm{N}_{80}+$ PK treatment, while with $\mathrm{N}_{160}+\mathrm{PK}$ treatment the production decreased significantly by $0.53 \mathrm{t} \mathrm{ha}^{-1}$ in the average of the hybrids. The values of $\mathrm{LSD}_{5 \%}$ between the plant number and the yield were: plant number: $0.48 \mathrm{t} \mathrm{ha}^{-1}$, hybrid: $0.31 \mathrm{t} \mathrm{ha}^{-1}$, interaction: $0.54 \mathrm{t} \mathrm{ha}^{-1}$. The optimum number of plants was affected at the greatest extent by the water and nutrient supply. Of course, with increasing the plant number the production per plant decreases, but the yield per unit area increases until a given point (up to the optimum plant number). The water demand of higher number of plants is also considerably higher, which was not satisfied.

\section{Figure 4: The effect of the increase of the number of plants on the yield of maize hybrids in $\mathbf{2 0 1 5}$ \\ ( $\mathrm{N}_{160}+\mathrm{PK}$, Hajdúszoboszló)}

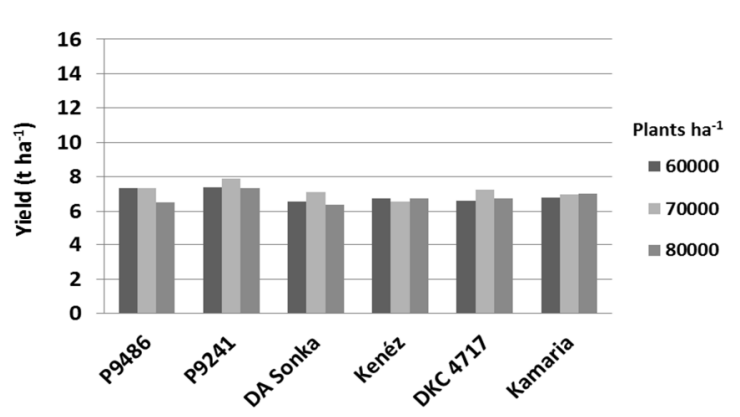

In 2016, with every hybrid, the yield could be increased with increasing the number of plants $\mathrm{ha}^{-1}$ even in treatments without fertilization (control treatment). The modern hybrids have a very good natural capability of nutrient uptake and usage, which is a genetically heritable characteristic.

Analysing the effect of increase in the plant number, in the average of the hybrids and fertilizer treatments, the following results are gained: with 60 thousand plants $\mathrm{ha}^{-1}$ the yield is $11.4 \mathrm{t} \mathrm{ha}^{-1}$, with increasing the plant number by 10 thousand it is 11.79 $\mathrm{t} \mathrm{ha}^{-1}$, and with the highest plant number of 80 plants $\mathrm{ha}^{-1}$ it is $12.38 \mathrm{t} \mathrm{ha}^{-1}$. So, increasing the number of plants from 60 thousand to 70 thousand resulted in a $0.4 \mathrm{t} \mathrm{ha}^{-1}$ increase in the yield, and further increase in the plant number increased the yield by a $0.6 \mathrm{t} \mathrm{ha}^{-1}$, in 2016. Thus, if 80 thousand plants ha $^{-1}$ were applied instead of 60 thousand, $1.0 \mathrm{t} \mathrm{ha}^{-1}$ yield increase could be detected. Obviously, it was mainly due to the favourable weather conditions. With $\mathrm{N}_{160}+\mathrm{PK}$ treatment, as it is shown in Figure 5, the effect of the plant number is evident, with increase in the plant number, the yield results also significantly increased. The value of $\mathrm{SzD}_{5 \%}$ was: plants ha $\mathrm{ha}^{-1} 0.15 \mathrm{t} \mathrm{ha}^{-1}$. In 2016, the highest yield $\left(13.81 \mathrm{t} \mathrm{ha}^{-1}\right)$ was produced by hybrid Kamaria, with the largest fertilizer dosage and the highest number of plants per hectare.

In 2017, the effect of the plant number was slighter. With $\mathrm{N}_{160}+\mathrm{PK}$ treatment, in most cases no significant difference could be observed. The values of $\mathrm{SzD}_{5 \%}$ were: plant number: $0.20 \mathrm{t} \mathrm{ha}^{-1}$, hybrid: 0.28 $\mathrm{t} \mathrm{ha}^{-1}$, interaction: $0.48 \mathrm{t} \mathrm{ha}^{-1}$. The hybrids with $\mathrm{N}_{160}+\mathrm{PK}$ treatment produced yields between 10.07 and $12.45 \mathrm{t} \mathrm{ha}^{-1}$ (Figure 6).

The maximum yield was achieved by hybrid P9486. In the average of the fertilizer treatments and the hybrids, the yield was $9.10 \mathrm{t} \mathrm{ha}^{-1}$ with 60 thousand plants $\mathrm{ha}^{-1}, 9.11 \mathrm{t} \mathrm{ha}^{-1}$ with 70 thousand plants $\mathrm{ha}^{-1}$ and $9.12 \mathrm{t} \mathrm{ha}^{-1}$ with 80 thousand plants $\mathrm{ha}^{-1}$. The response of the hybrids to the change in the plant number was 
detectable only with the control treatment (without fertilization), where 60 thousand plants $\mathrm{ha}^{-1}$ was the most favourable stand density in terms of the yield, and the differences between the results gained with the different plant numbers caused by fertilization were moderate.

Figure 5: The effect of the increase of the number of plants on the yield of maize hybrids in 2016 ( $\mathbf{N}_{160}+$ PK, Hajdúszoboszló)

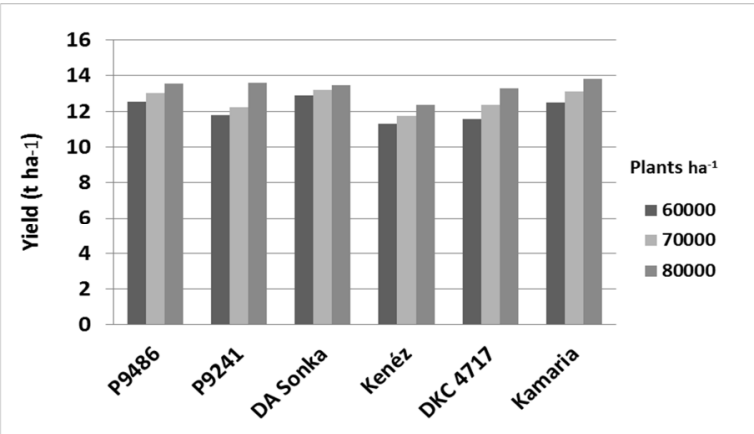

Figure 6: The effect of the increase of the number of plants on the yield of maize hybrids in 2017 ( $\mathbf{N}_{160}+\mathrm{PK}$, Hajdúszoboszló)

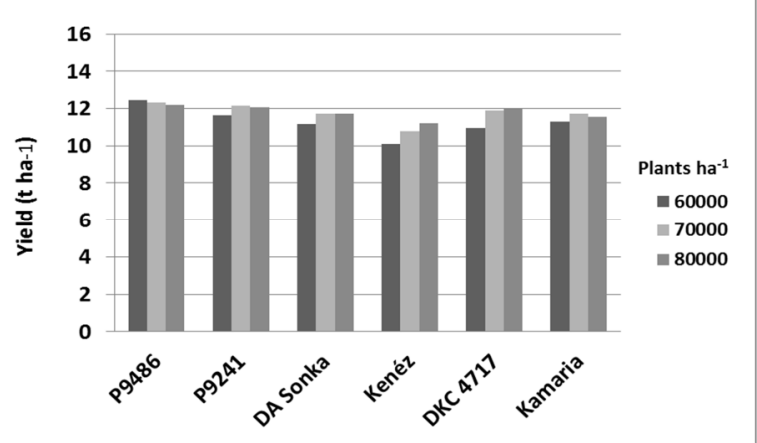

The adverse effects of the weather in 2015 were reflected in the results of our experiment. The yield of the hybrids, in the average of the different plant numbers, without fertilization, changed between 5.28 and $7.13 \mathrm{t} \mathrm{ha}^{-1}$. The yield of the six tested hybrids, in the average of the different plant numbers, without fertilization, is $6.33 \mathrm{t} \mathrm{ha}^{-1}$, and compared to that, with the $\mathrm{N}_{80}+\mathrm{PK}$ treatment it is $7.14 \mathrm{t} \mathrm{ha}^{-1}$. Increase in the yield is only $0.81 \mathrm{t} \mathrm{ha}^{-1}$, but it is significant. Due to the especially droughty weather, the yield increasing effect of fertilizer was moderate, moreover, with increasing the fertilizer dosage the yield had not increased but decreased by $0.18 \mathrm{t} \mathrm{ha}^{-1}$, which can be explained by the lack of water during flowering, fertilization and grain filling (Figure 7).

In 2016, the effects of the fertilizer treatments exceedingly prevailed. Compared to the $\mathrm{N}_{80}+\mathrm{PK}$ treatment, the $\mathrm{N}_{160}+\mathrm{PK} \mathrm{kg} \mathrm{ha}{ }^{-1}$ fertilizer significantly increased the yield. Compared to the control treatment (10.65 $\left.\mathrm{t} \mathrm{ha}^{-1}\right)$, the $\mathrm{N}_{80}+\mathrm{PK}$ treatment $\left(12.24 \mathrm{t} \mathrm{ha}^{-1}\right)$ increased the yield by $1.6 \mathrm{t} \mathrm{ha}^{-1}$, while with the $\mathrm{N}_{160}+\mathrm{PK}$ treatment $\left(12.69 \mathrm{t} \mathrm{ha}^{-1}\right)$ a further $0.6 \mathrm{t} \mathrm{ha}^{-1}$ yield increase could be generated, in the average of the hybrids and the different plant numbers. With the $\mathrm{N}_{160}+\mathrm{PK}$ treatment the highest yields (13.48-13.81 t $\mathrm{ha}^{-1}$ ) were produced by hybrids Kamaria, DA Sonka, P9486 and P9241, with 80 plants ha ${ }^{-1}$.

By the third year of the experimental period, the nutrient content of the plots that were not treated with fertilizers had become appreciably low, thus there were significant differences between the yield results gained with the control and with the other fertilizer treatments. In the average of the hybrids and the plant numbers, the yields were $5.61 \mathrm{t} \mathrm{ha}^{-1}$ and $10.12 \mathrm{t} \mathrm{ha}^{-1}$, respectively, while with the highest fertilizer dosage it was $11.61 \mathrm{t} \mathrm{ha}^{-1}$. The response of hybrid P9486 to the fertilizer treatments clearly show that, in the average of the different plant numbers, compared to the control treatment, with applying the $\mathrm{N}_{80}+\mathrm{PK}$ treatment the yield increased by $5.39 \mathrm{t} \mathrm{ha}^{-1}$ (Figure 7).

Figure 7: The effect of NPK fertilization and the crop year in the average of the numbers of plants ha ${ }^{-1}$ (Hajdúszoboszló, 2015-2017)

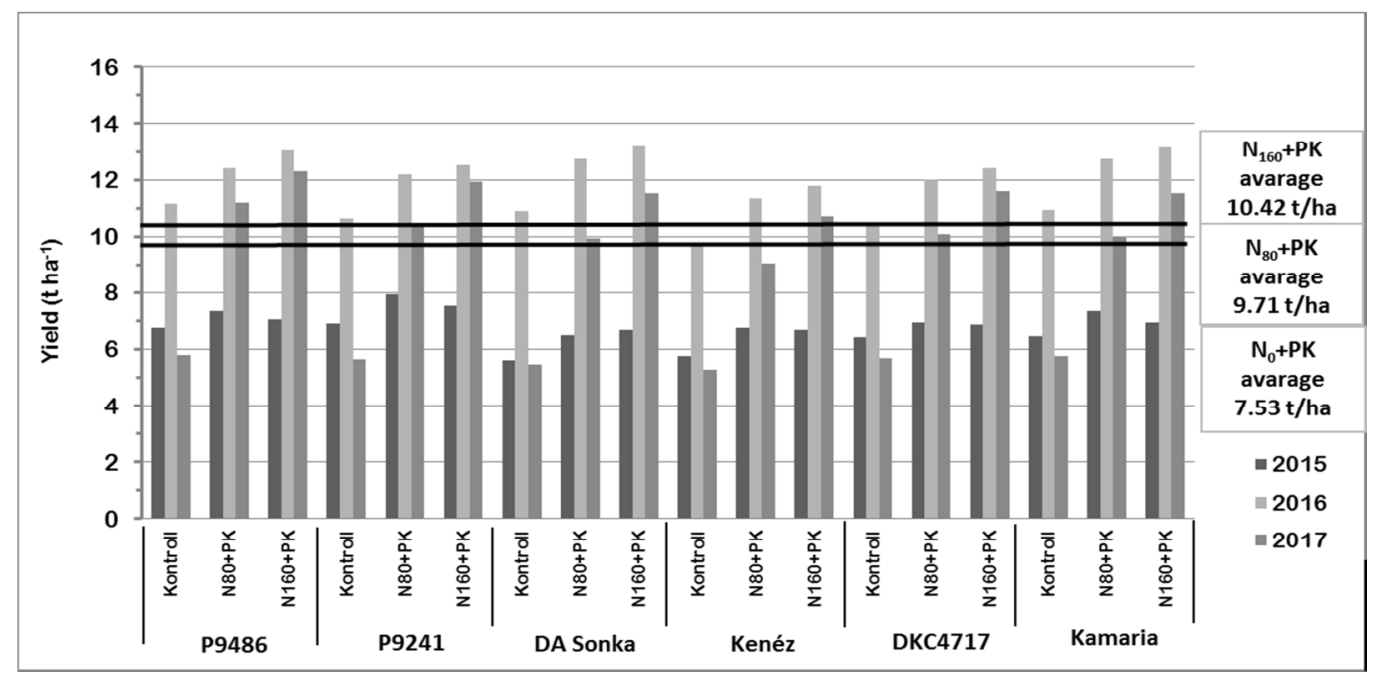


Evaluating the three years in the average of the different plant numbers, with the treatment without fertilization, the average yield of the hybrids was 7.53 t ha'. With the $\mathrm{N}_{80}+\mathrm{PK}$ treatment it was $9.71 \mathrm{t} \mathrm{ha}^{-1}$, and with doubling the fertilizer dosage it increased to $10.42 \mathrm{t} \mathrm{ha}^{-1}$. Compared to the control, each unit of increase in the fertilizer dosages resulted in $2.18 \mathrm{tha}^{-1}$ yield increase, and further increase in the fertilizer dosage caused $0.71 \mathrm{t} \mathrm{ha}^{-1}$ increase in the yield. These values are shown in Figure 8 , where the $10.42 \mathrm{t} \mathrm{ha}^{-1}$ value is taken as $100 \%$.

\section{Figure 8: The effect of NPK fertilization in the average of the hybrids and the numbers of plants ha ${ }^{-1}$ (Hajdúszoboszló, 2015-2017)}

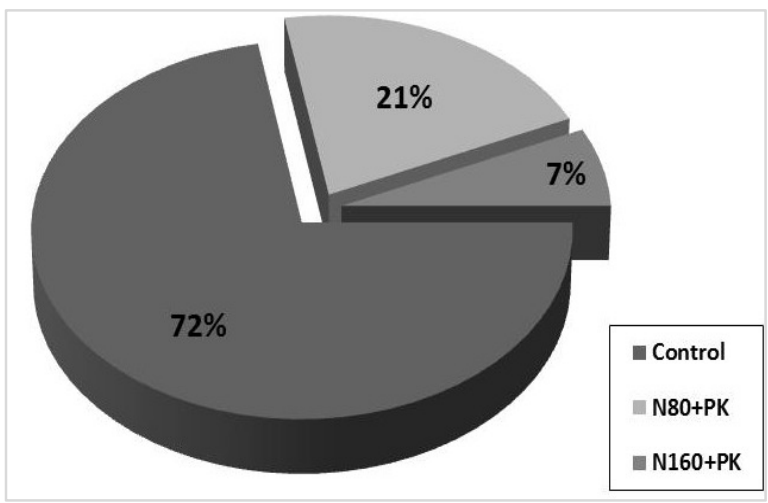

\section{CONCLUSIONS}

If we express the fertilization results of the three years in numbers, it can be assessed that, compared to the control, the $\mathrm{N}_{80}+\mathrm{PK}$ dosage caused a $2.18 \mathrm{t} \mathrm{ha}^{-1}$ increase in yield, and further increase of the fertilizer dosage $\left(\mathrm{N}_{160}+\mathrm{PK}\right)$ produced a further $0.71 \mathrm{t} \mathrm{ha}^{-1}$ yield increase. If we calculate the price of $80 \mathrm{~kg} \mathrm{~N}, 60 \mathrm{~kg}$ $\mathrm{P}_{2} \mathrm{O}_{5}$ and $70 \mathrm{~kg} \mathrm{~K} \mathrm{~K}_{2} \mathrm{O}$ active agent, it amounts to 40,000 HUF. If we compare this cost to the observed yield increase, it can be concluded that the $\mathrm{N}_{160}+\mathrm{PK}$ fertilizer had not returned the price of the input; therefore, it was not saving to apply (1 tonne of maize is approx. 40,000 HUF). Of the different fertilizer dosages, $\mathrm{N}_{80}+\mathrm{PK}$ can be considered ideal. As written in the introduction, "the appropriate nutrient supply determines yield in 26\% according to Györffy (1976), in $30.6 \%$ according to Berzsenyi et al. (2011), in $48 \%$ according to Nagy (1996), and in $39.3 \%$ according to Pepó and Csajbók (2014)". In our experiment according to the analysis of 3 years, the appropriate nutrient supply affected the yield in $28 \%$.

From the results of the increase of the population density, the following can be concluded. In adverse weather conditions (2015) the lower plant number (60 thousand), while in favourable conditions (2016) the higher plant number ( 80 thousand) resulted in the best yield results. In an average crop year (2017) the effects of the different plant numbers prevailed to a smaller extent. Thus, we can conclude that, as we cannot predict the weather conditions, the application of an average of 70 thousand plants $\mathrm{ha}^{-1}$ stand density can provide the highest yield stability.

\section{REFERENCES}

Berzsenyi, Z.-Árendás, T.-Bónis, P.-Micskei, G.-Sugár, E. (2011) Long-term effect of crop production factors on the yield and yield stability of maize in different years. Acta Agronomica Hungarica. 59. 3: 191-200.

Berzsenyi Z.-Győrffy B. (1997): Az istállótrágya és mütrágya hatása a kukorica (Zea mays L.) termésére és termésstabilitására tartamkísérletben. Növénytermelés. 46. 5: 509-527.

Bocz E. (1981): A növénytermesztés ösztönző támogatása. Magyar Mezőgazdaság. 36. 27: 9.

Futó Z.-Sárvári M. (2015): A kukoricatermesztés technológiájának fejlesztési lehetőségei. Szent István Egyetem Kiadó. Gödöllő. 22-27.

Győrffy B. (1976): A kukorica termésére ható növénytermesztési tényezők értékelése. Agrártudományi Közlemények. 35. 1-3: 239-266.

Lente Á.-Pepó P. (2009): Az évjárat és néhány agrotechnikai tényezö hatása a kukorica termésére csernozjom talajon. Növénytermelés. 58. 1: 39-51.

Marton L. Cs. (2014): A kukorica termésátlagok alakulása a világban és itthon. Az MTA Agrártudományi Kutatóközpont Közleményei. Martonvásár. 26. 2: 4-5.

Nagy J. (1995): A mütrágyázás hatásának értékelése a kukorica (Zea mays L.) termésére eltérő évjáratokban. Növénytermelés. 44. 4: 493-506.

Nagy J. (2006): Az évjárat hatásának értékelése a kukorica termésére. Növénytermelés. 55. 5-6: 299-308.
Nagy J. (2017): Klímaváltozás és a mütrágyázás hatása a kukorica termésére debreceni tartamkísérletben. Növénytermelés. 66. 3: $11-32$.

Nagy J.-Huzsvai L. (2005): Hibridválasztás a kukoricatermesztés középpontjában. Gyakorlati Agrofórum. 16. 9: 30-32.

Nagy, J. (1996): Effect of tillage, fertilization plant density and irrigation on maize yields. Acta Agronomica Hungarica. 44. 4: 347-354.

NAK (2017): NAK Mezőgazdasági Igazgatóság összeállítása, a NAK megyei Igazgatóságainak adatai alapján. www.nak.hu

Pepó P. (2006): Fejlesztési alternatívák a magyar kukorica termesztésben. Gyakorlati Agrofórum. 17. 13: 7-11.

Pepó P.-Csajbók J. (2014): Agrotechnikai tényezök szerepe a kukorica (Zea mays L.) termesztésében. Növénytermelés. 63. 2: 45-68.

Pepó P.-Szabó P.-Szieberg D. (2002): Az állománysürüség szerepe a fajtaspecifikus kukoricatermesztésben. Agrofórum 13. 3: 34-36.

Rácz Cs.-Nagy J. (2011): A víz- és tápanyagellátottság, illetve hasznosulás megítélésének kérdései kukorica terméseredmények vonatkozásában. Növénytermelés. 60. 1: 97-114.

Sárvári M. (2006): A vetésváltás és a tőszám hatása a kukorica hibridek termésére. [In: Pepó P.-Vladimir, P. (eds.) Rationalization of Cropping System and Their Effect on The Effective Utilisation of Yield Potential and Quality of Field Crop Production under Sustainable Development. SlovakHungarian Project. (CD-kiadvány) 25-45. 